研究速報・Short Communication

\title{
蛍光塗料浸透法によるセラミックスの巨視的き裂観察
}

\author{
松尾陽太郎・小笠原俊夫 ・北林徹夫 · 安田榮一* · 木 村 脩七 \\ $\left(\begin{array}{rl}\text { 東京工業大学 } & \text { 工学部 } \\ * \text { 無機材料工学科 }\end{array}\right)$
}

(1985 年 7 月 16 日受付)

\section{Observations of Macro-Cracks by Fluorescent Dye Penetration}

\author{
Yohtaro MATSUO, Toshio OGASAWARA, Tetsuo KITABAYASHI, \\ Eiichi YASUDA* and Shiushichi KIMURA

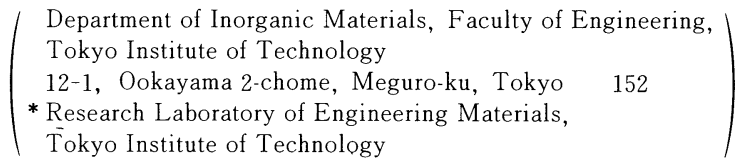

[Received July 16, 1985]

\begin{abstract}
Key-words : Fluorescent dye, Macroscopic crack, Alumina, 4-point bending test, Vickers indentation, Uni-axial compression
\end{abstract}

蛍光塗料をセラミックスの巨視的な表面き裂に浸透さ せ,これに紫外線を照射すると, き裂中に浸透した蛍光塗 料が蛍光を発し，き裂進展の様子を比較的容易に観察す ることができる ${ }^{1 !}$.この方法を用いて 4 点曲げ試験後の 破断試料, ビッカース圧子圧入後の圧痕形態並びに圧縮 試験後の試料に進展した巨視的き裂の観察を行った結 果, 破面観察が比較的困難であるアルミナ試料について も破壊源の推定並びにき裂進展の様子が推定可能となっ たので，その結果を報告する.

実験に用いた蛍光塗料は日本油脂製ケイコーチェック $\mathrm{N}-5 \mathrm{P}$ であり, 約 $360 \mathrm{~nm}$ の紫外線源を用いて発光させ た. 4 点曲げ試験及びビッカース圧子圧入の試料として は日本化学陶業製アルミナSSA-S (A) (平均粒径 $2 \mu \mathrm{m}$, 最大粒径 $10 \mu \mathrm{m}$ ，かさ密度 3.83 , 純度 $99.56 \%$ ) を用い, 試料形状は $50 \times 10 \times 3(\mathrm{~mm})$ の短冊型とした。また圧 縮試験には千葉セラミックス工業製アルミナ (平均粒径 $4 \mu \mathrm{m}$, 最大粒径 $10 \mu \mathrm{m}$, 最大気孔径 $30 \mu \mathrm{m}$, 加さ密度 3.55 , 純度 $96 \%)$ を $8 \times 8 \times 17(\mathrm{~mm})$ の角柱に切り出 して用いた。

\section{4 点曲げ試験後の破断試料の観察}

曲げ試験はすべて 4 点曲げ試験法で行い，試験機には 島津製作所製オートグラフ DSS-25 Tを用いた。また 上部スパン, 下部スパンをそれぞれ $13.3 \mathrm{~mm}, 40.0 \mathrm{~mm}$,

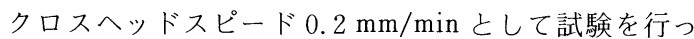
た. 曲げ試験後の試料は直接蛍光塗料に浸した後, 余分 な塗料を落とすため水洗してから，紫外線を照射してき 裂の観察を行った。肉眼並びに光学顕微鏡観察による大 部分の試験片の破断面は一つないしは二つであって，ほ かにき裂は見られないが，蛍光観察によると破断した試 料中には破壊源を起点とした複数のき裂が 2 本ずつ樹枝 状に分岐しながら進展していることが分った。このよう なき裂の分岐を観察することにより，おおよその破壊源 の位置を推定することが可能である．例えば図 1 (a) は 試料のほぼ中央から，図 1 (b) はコーナ一から破壊し たことが推定できる。また図 1 (c) は図 1 (a) の破断面 を見たもので，これより破壊源が材料の表面付近である ことが推定できる．これらの観察デー夕（破壊原因デー 夕）を用いることにより，デー夕解析の精度を飛躍的に 向上させることが可能である.

\section{2. ビッカース圧子圧入後の圧痕の観察}

試料は表面を\#1000のダイヤモンドホイールで研削 した後，1 $1 \mu \mathrm{m}$ のダイヤモンドペーストでラッピングを 行った。オートグラフを用いてビッカース圧子を，試料 片中央付近にクロスヘッドスピード $0.05 \mathrm{~mm} / \mathrm{min}$, 最 大荷重 $30 \mathrm{kgf}$, 印加時間 30 秒で圧入した.このとき, あらかじめ圧子の先端に蛍光塗料をつけておき，き裂に 


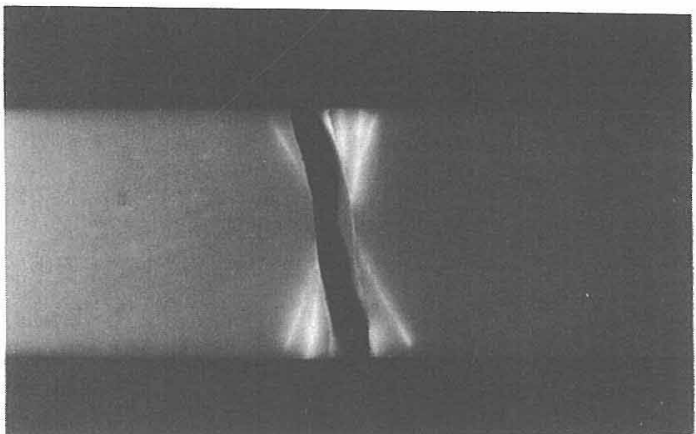

( a )

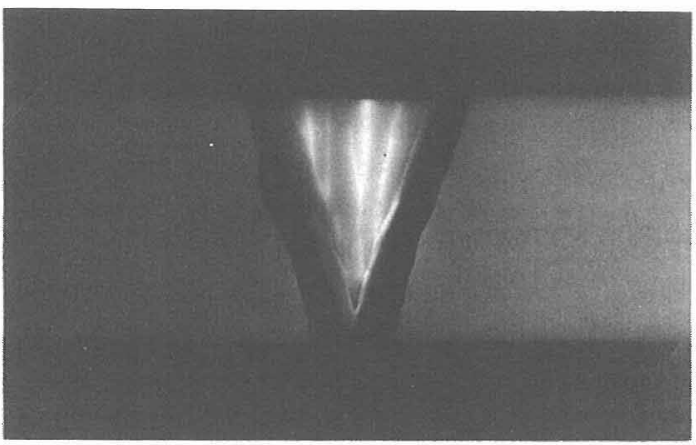

(b )

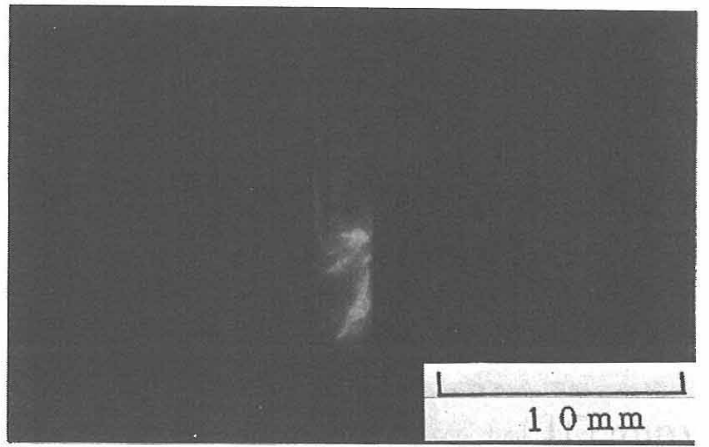

(c)

Fig. 1. Photographs of alumina specimens fractured after 4-point bending test. Specimens were immersed in fluorescent dye and observed under U.V. light. Observed fracture origins are :

(a) At the center, (b) At the edge, (c) At the surface

塗料が浸透するようにした。圧子王入後武料を水洗し， 反射顕微鏡を用いて紫外線下でのき裂観察を行った結 果,メジアンノラジアルき裂がかなりはっきりと観察可 能であることが分った（図 $2(\mathrm{a})$ ).

次にこの圧子圧入した試料の 4 点曲げ式験を行い (IIF 法), 反射顕微鏡を用いて破断面 (圧子圧入痕) の観察を行った（図 2 (b)). 同図よりメジアンノラジ アルき裂が材料中に深く導入されていることに加えて， 蛍光塗料の浸透により，プロセスゾーンのおおよその大 きさと形状も観察することができた。

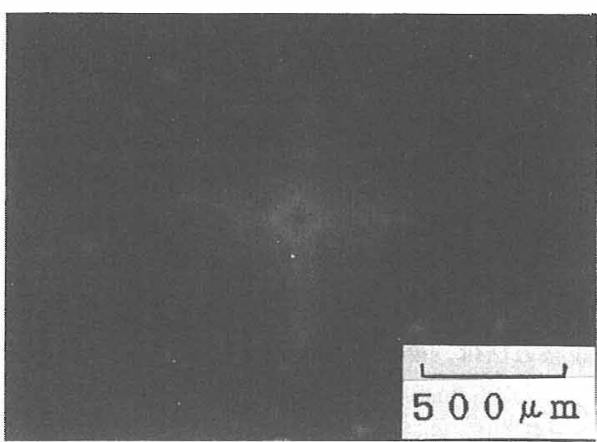

(a)

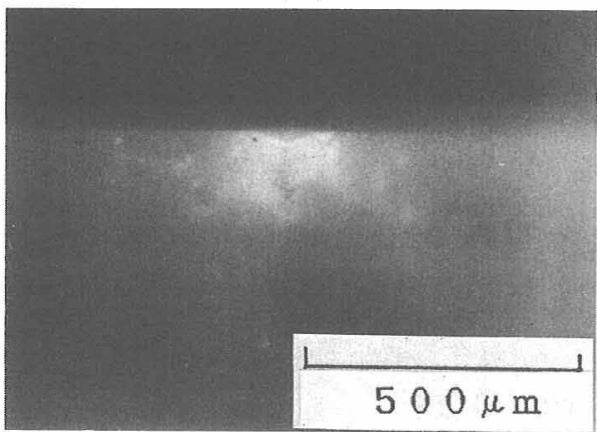

( b )

Fig. 2. Optical micrographs of alumina specimens.

(a) Median/radial crack systems by Vickers indentation,

(b) Fractured surface by 4-point bending test after $30 \mathrm{kgf}$ Vickers indentation load

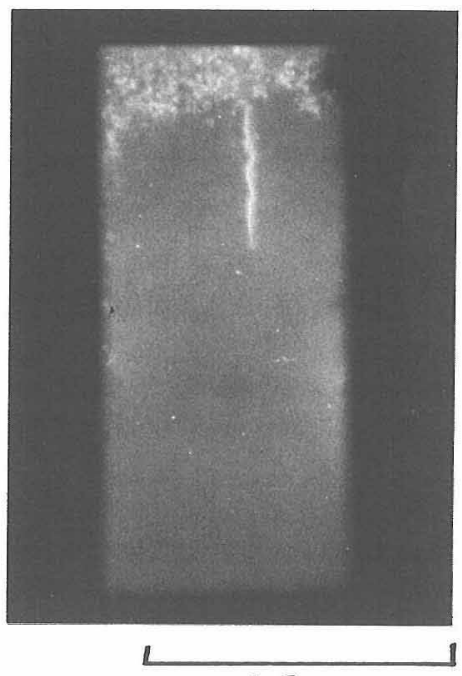

$10 \mathrm{~mm}$

Fig. 3. Cracks parallel to the loading axis induced by uni-axial compression.

\section{3. 圧縮試験後のき裂観察}

試料の上下面にビニールはく（管）を介してWC 板 により圧縮試験を行った。クロスヘッドスピードは 0.1 $\mu \mathrm{m} / \mathrm{min}$ とし, WC 板に取りつけた AEトランスデュー 
サーにより試料からの AE を検知した直後に負荷を中 断した.この試料に減圧下で蛍光塗料を浸透させ, 紫外 線光源を付けた反射顕微鏡によりき裂を観察した. 図3 に示すように試料中央に圧縮軸に平行なき裂が観察され た.

このように蛍光塗料浸透によるセラミックスの表面き 裂の観察方法は, 操作が極めて簡便であり, 巨視的なき
裂 (数百ミクロン以上) を直接観察することができるた め, 多数の試料や比較的大きな材料の破壊源を推定する ときに有効であろう.

謝辞蛍光塗料を提供して頂きました日本油脂(株)の鶴 岡和男, 容崎邦寛, 中野幹夫の各氏に深く感謝致します.

\section{文献}

1) 例えば, K. T. Faber, M.D. Huang and A. G. Evans, J. Am. Ceram. Soc., 64, 296-301 (1981).

\section{訂 正}

窯業協会誌 93 ［8］467-74（1985）掲載の，青木繁樹・木曽正光・荒井康夫 “製紙スラッジ-硫 酸一高炉水砕スラグ-水酸化カルシウム系の凝結硬化とアルミン酸ナトリウム添加の影響” の 470 ページ左段図 4 のキャプションは下線の個所を訂正致します.

Fig. 4. X-ray diffraction patterns of solid phases during setting in paper sludge $200 \mathrm{~g}-\underline{15} \% \mathrm{H}_{2} \mathrm{SO}_{4}$ $200 \mathrm{ml}-\mathrm{slag} 100 \mathrm{~g}-\mathrm{Ca}(\mathrm{OH})_{2} 50 \mathrm{~g}$. P : Paper sludge, G : $\mathrm{CaSO}_{4} \cdot 2 \mathrm{H}_{2} \mathrm{O}, \mathrm{E}:$ Ettringite, $\mathrm{L}: \mathrm{Ca}(\mathrm{OH})_{2}$ 